\title{
EVALUATING VOLUMETRIC GLACIER CHANGE METHODS USING AIRBORNE LASER SCANNING DATA
}

\author{
PHILIP CLAUDIO JOERG and MICHAEL ZEMP
}

Department of Geography, University of Zurich, Zurich, Switzerland

Joerg, P.C. and Zemp, M., 2014. Evaluating volumetric glacier change methods using airborne laser scanning data. Geografiska Annaler: Series A Physical Geography, 96, 135-145. DOI:10.1111/geoa.12036

ABSTRACT. Assessments of geodetic volume change are widely used in glaciology and have a long tradition dating back to the nineteenth century. Over time, the geodetic method and corresponding data storage have been developed further, but the resulting methodological heterogeneity can lead to errors that are difficult to separate from other survey uncertainties. In this study we used high-resolution airborne laser scanning data from the Findelengletscher in the Swiss Alps to evaluate state-of-the-art volumetric glacier change methods. For the first time we have been able to simulate errors arising from different geodetic methods and spatial resolutions. The evaluation showed that, although the digital elevation models were perfectly co-registered, systematic and random method- and scale-dependent errors still occurred. These errors have an impact on the resulting volume changes at lower spatial resolutions and may lead to exponentially larger uncertainties. Volume changes from contour methods provided reasonably accurate results, while volumetric change assessments from central profile lines were especially prone to biases at any scale.

Key words: airborne laser scanning, LiDAR, glacier change, geodetic volume change, method comparison, uncertainty analysis

\section{Introduction}

Glacier changes are considered to be among the best natural indicators of climatic changes and can have severe impacts on natural hazards, the regional water cycle, and global sea level (WGMS 2008). Geodetic methods for assessing changes in glaciers' area, thickness, and volume have a long tradition in glaciology with high-quality topographic mapping reaching back to the late nineteenth century (Finsterwalder 1897; Mercanton 1916). Such data have been compiled and published by the World Glacier Monitoring Service and its predecessor since the 1960s (PSFG 1967; WGMS 2012). The results from the geodetic assessments are used to validate and calibrate the glaciological method (Zemp et al. 2013) and to extrapolate from the results of the limited glaciological sample in space and time (Cogley 2009; Zemp et al. 2009). The geodetic method has been further developed to include new sensors (triangulation, photogrammetry, laser profiling and scanning), platforms (terrestrial, airborne, spaceborne), and data storage types (contour maps, vector and raster datasets, digital point clouds). However, it is difficult to separate errors related to these acquisition heterogeneities from other error sources and related uncertainties and have only been assessed in a few studies (e.g. Reinhardt and Rentsch 1986).

Our study site comprised a $28 \mathrm{~km}^{2}$ catchment area containing the Findelengletscher $\left(46^{\circ} \mathrm{N}, 7^{\circ}\right.$ $52^{\prime}$ E) in Canton Valais, Switzerland. This valleytype glacier is $13 \mathrm{~km}^{2}$ in area (2010) with an elevation range of 2600-3900 m a.s.l. Between 2005 and 2010, the average annual thickness change of Findelengletscher was $-0.7 \mathrm{~m}$ with mean elevation changes of up to $-7 \mathrm{~m}$ at the tongue and $-0.2 \mathrm{~m}$ in the accumulation area (Joerg et al. 2012). During these five years, the glacier retreated by approximately $200 \mathrm{~m}$ and lost $2 \%$ of its area.

The specific annual mass balances were, according to in-situ ablation-stake and snow-pit measurements, $-7.3 \mathrm{~m}$ water equivalent (w.e.) at the terminus and $+1 \mathrm{~m}$ w.e. in the accumulation area, resulting in an average annual mass balance of $-0.41 \mathrm{~m}$ w.e. for the whole glacier (WGMS 2012). The expected annual mass turnover of the Findelengletscher is approximately $1.1 \mathrm{~m}$ w.e. if the winter of 2010 is assumed to be unexceptional (Sold et al. 2013).

We used high-resolution laser scanning data from two airborne surveys of the Findelengletscher, as a validation dataset to derive changes in glacier volume by simulating different established geodetic methods at various spatial scales. We then 
evaluated any systematic and random errors due to methodological differences. In addition, we discuss the relevance of these errors for the interpretation of geodetic results.

\section{Data and methods}

Laser scanning surveys

The Findelengletscher was mapped using multitemporal digital elevation models (DEMs) from airborne laser scanning (ALS) (Joerg et al. 2012). The elevation models used here cover the five-year period from October 2005 to September 2010 and were available as point clouds with average point densities of 1.1 points (pts) $\mathrm{m}^{-2}$ in 2005 and 14.3 pts $\mathrm{m}^{-2}$ in 2010 (Table 1).

Additionally, two synchronous flight trajectories (September 2010) with a higher flying altitude covered a large part of the study site to investigate the effect of a lower point density on the accuracy of the subsequently derived DEM. When planning an airborne laser scanning campaign, the target number of points per square meter is required to generate a flight plan. The price of the dataset depends on the point density and the survey area. To simulate the accuracy for a much larger region, we tested the cheapest flight setup possible in addition to our high point density setups. We ended up with two flight lines covering close to $90 \%$ of Findelengletscher, with an average point density of $0.4 \mathrm{pts} \mathrm{m}^{-2}$. The high point density flight plan (yellow lines in Fig. 1) used 35 flight trajectories with a combined length of more than $180 \mathrm{~km}$ to cover the area of Findelengletscher (and Adlergletscher to the north), with a total flight time of $4 \mathrm{~h}$. Compared with this setup, the low point density campaign needed only about $17 \mathrm{~km}$ with a flight time of $12 \mathrm{~min}$. Based on this information, we cal- culated that the low point density data would cost only about $10 \%$ of the cost of the high point density setup. Note that the fixed costs for the flight to and from the area of interest are not included in this calculation. Moreover, the covered and overlapping area are smaller in the low point density setup (see footprint in Fig. 1).

\section{Volume change from high ALS point density}

As a reference for all subsequent methods and resolutions, we used the two high point density ALS point clouds acquired in fall 2005 and 2010 to interpolate each into a $1 \times 1 \mathrm{~m} \mathrm{DEM} \mathrm{(Fig.} \mathrm{2a,} \mathrm{b).} \mathrm{To}$ perform this task, the average elevation of all laser points on the ground (outliers previously removed) within a given $1 \times 1 \mathrm{~m}$ raster cell was assigned as the elevation of that cell. Subsequently, to allow the calculation of the change in volume of the entire glacier, empty raster cells were interpolated using a least squares approach without changing the existing values (Joerg et al. 2012). The elevation change was then calculated by subtracting elevations at the same coordinates from each other (Fig. 2c). Subsequently, to calculate the average glacier elevation change, all elevation changes were summed up for the entire glacier area and divided by the average glacier surface area on the two dates.

To simulate the effect of scale from different raster resolutions, we repeatedly calculated the volume change while increasing the raster cell size in $1 \mathrm{~m}$ steps from $1 \times 1 \mathrm{~m}$ to $250 \times 250 \mathrm{~m}$. In a first step, elevation values outside the glacier extent of 2005 were clipped for both DEMs in MATLAB (The MathWorks, Inc.) and set to 'no data' in the $1 \times 1 \mathrm{~m}$ resolution grid to avoid using values outside the glacier for the change calculations. In a next step, the lower resolution raster grids were defined

Table 1. ALS data acquisition parameters and flying heights for the different dates.

\begin{tabular}{|c|c|c|c|c|}
\hline Parameter & & $\begin{array}{c}28-29 \text { October } \\
2005\end{array}$ & $\begin{array}{c}29 \text { September } \\
2010\end{array}$ & $\begin{array}{c}29 \text { September } \\
2010\end{array}$ \\
\hline Sensor employed & ALTM & 3100 & Gemini & Gemini \\
\hline Measuring frequency & $(\mathrm{kHz})$ & $71-100$ & 71 & 33 \\
\hline Scanning angle & $\left({ }^{\circ}\right)$ & \pm 23 & \pm 15 & \pm 20.1 \\
\hline Scanning frequency & $(\mathrm{Hz})$ & $40-50$ & 39 & 13.7 \\
\hline Average flying height & (m) & 1500 & 1000 & 2800 \\
\hline Across-track overlap & $(\%)$ & 55 & 50 & 35 \\
\hline Average point density & $\left(\right.$ pts $\mathrm{m}^{-2}$ ) & 1.1 & 14.3 & 0.4 \\
\hline LASER Wavelength & $(\mathrm{nm})$ & 1064 & 1064 & 1064 \\
\hline Beam divergence (1/e) & (mrad) & 0.30 & 0.25 & 0.25 \\
\hline Footprint size & (m) & 0.45 & 0.25 & 0.70 \\
\hline
\end{tabular}




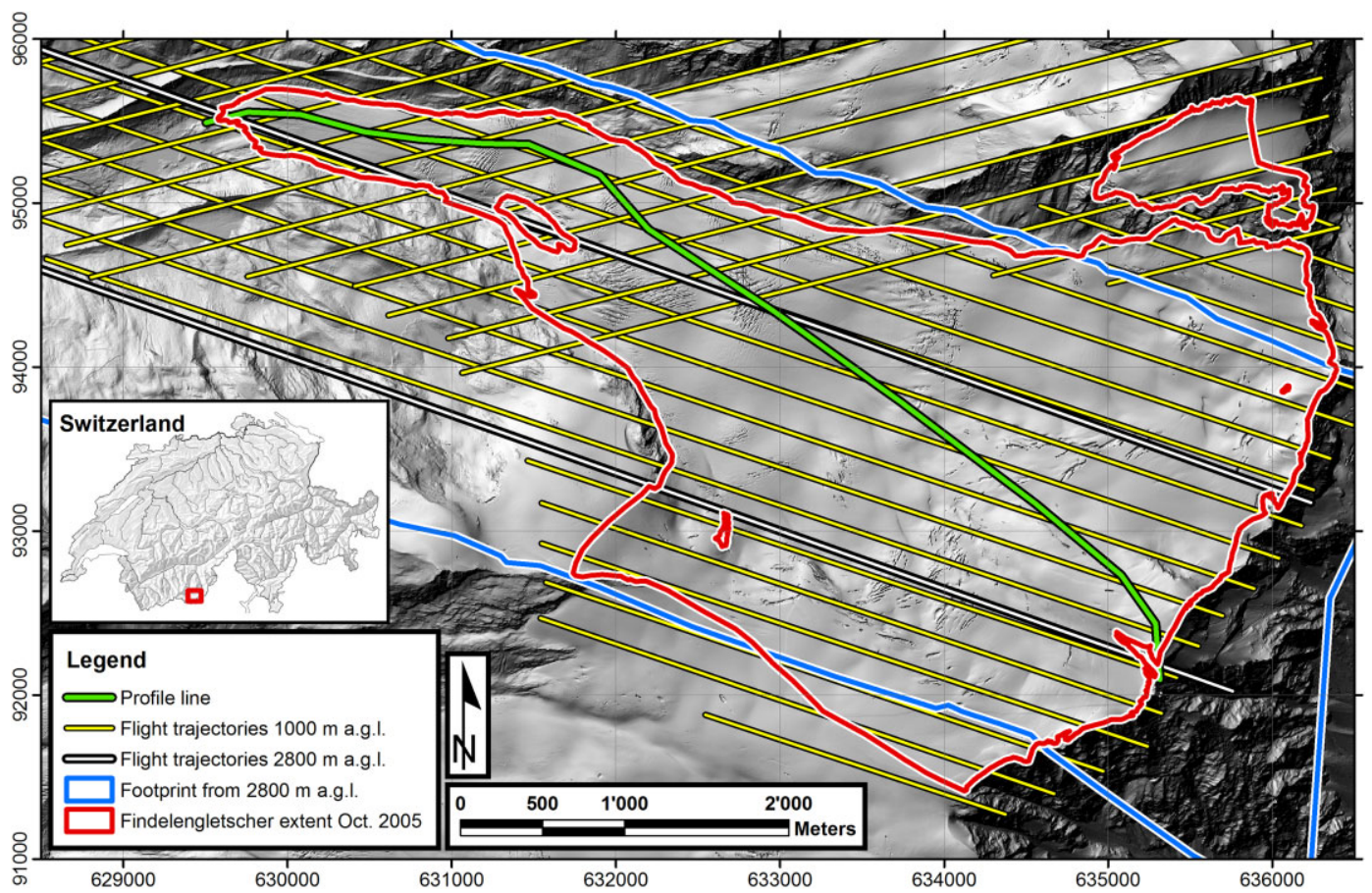

Fig. 1. Shaded relief of the Findelengletscher area. The red line shows the glacier extent in October 2005, and the green line the profile. Yellow lines indicate the flight trajectories of the high-resolution campaigns, the two white tracks (with black outlines) the two high flight trajectories, and the blue tracks the corresponding area covered on the ground. Coordinates are taken from Swiss grid CH1903, in meters.

similarly in both ALS datasets and filled with interpolated elevation values from the high-resolution raster using a bi-linear approach (the 'interp2' function in linear mode in MATLAB). The new grid intersection value is therefore the interpolation of the four nearest $1 \times 1 \mathrm{~m}$ grid points. In the global grid definition process, the cell centre of the most southwesterly raster cell was kept at the same coordinates, whereas all other coordinates were generated according to the new raster resolution. Finally, both new rasters were subtracted from each other and the volume change was calculated.

\section{Volume change from low ALS point density}

On the same day the high point density dataset of September 2010 was acquired, a low point density dataset was obtained to test the most economical way to generate an ALS DEM and to investigate the effects of the lower point density on the volume change. The footprint of the two flight trajectories covered about $90 \%$ of Findelengletscher's surface (Fig. 1). We calculated the volume change per
$10 \mathrm{~m}$ elevation band by extrapolating the measured average volume change to the unmeasured areas. The overall volume change is the sum of the volume changes of all elevation bands. As the unmeasured area was exclusively located on high elevations in the accumulation area with little volume change, the error introduced by the extrapolation is expected to be small.

\section{Volume change from an altimetry profile}

To survey a large number of glaciers, laser profiling along the centreline instead of laser scanning provides the elevation change distributed over the entire altitudinal range of a glacier (cf. Arendt et al. 2002). This approach was simulated by measuring elevation changes of Findelengletscher (Fig. 1) by using all DEM elevations of 2005 and 2010 of $1 \times 1 \mathrm{~m}$ grid cells along the centreline. Additionally, a horizontal distance of $25 \mathrm{~m}$ between surveyed points was simulated to reveal the influence of scale in the horizontal sampling distance. Subsequently, we calculated 

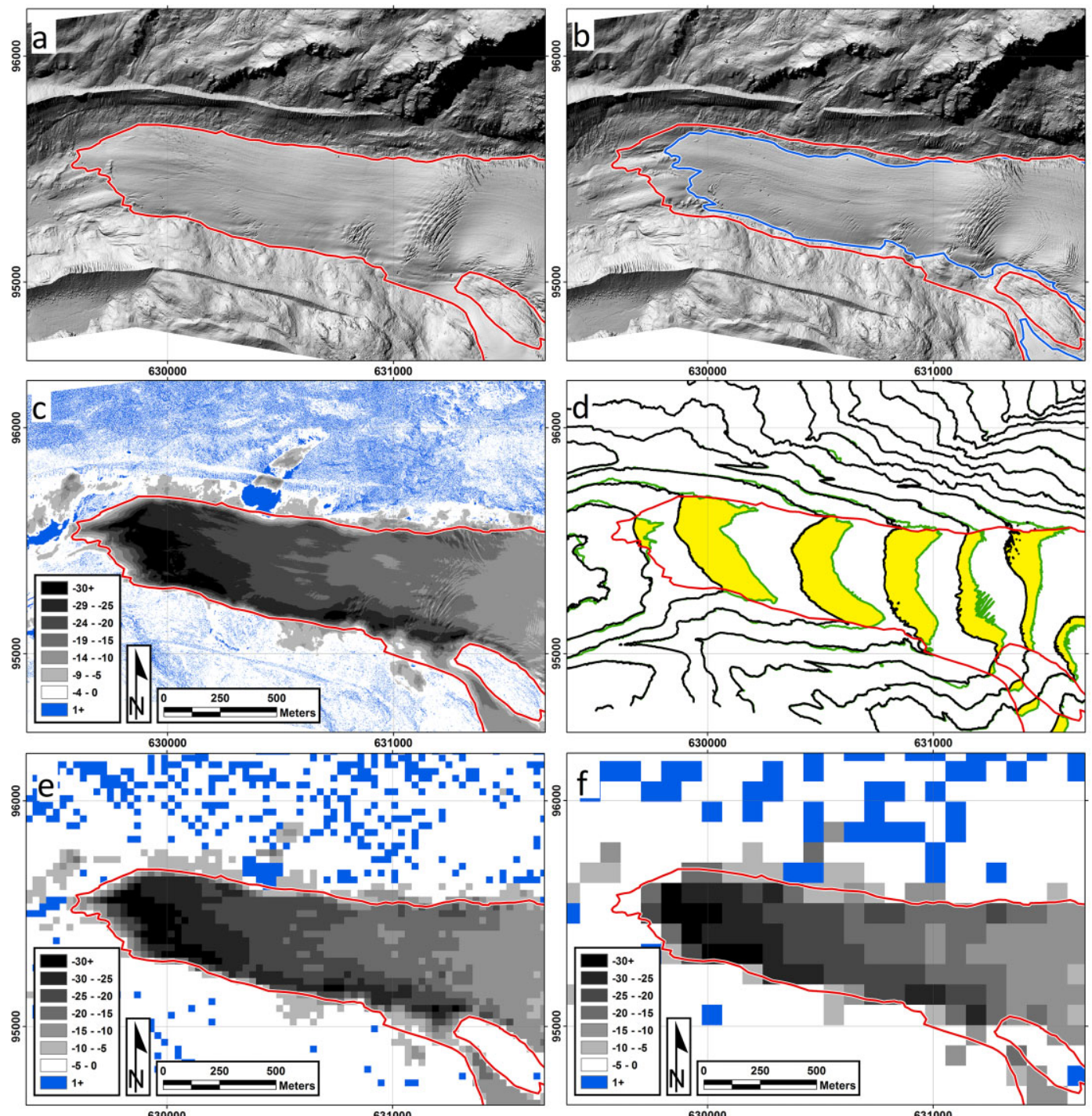

Fig. 2. Changes in the Findelengletscher tongue with the areas and hillshaded elevation models in 2005 (red; a) and 2010 (blue; b). Note the retreat of the tongue by approx. $200 \mathrm{~m}$ and the collapsing moraine to the north of the tongue (b). The middle row shows the elevation change in meters from the $1 \times 1 \mathrm{~m}$ ALS DEMs (c) and an example of $50 \mathrm{~m}$ contour lines (d; 2005: black, 2010: green) with yellow areas showing the area differences used for the volume change calculations. The bottom row shows the elevation change of $30 \mathrm{~m}$ (e; similar to ASTER GDEM) and $90 \mathrm{~m}$ (f; similar to SRTM DEM), with resampled DEMs using the same elevation change colours as the $1 \times 1 \mathrm{~m}$ DEM. Numbers in the legends are meters elevation change.

the average elevation change within every $10 \mathrm{~m}$ elevation band and multiplied that change with the mean 2005/2010 area of that corresponding elevation band. The overall volume change was then calculated by summing up all volume changes.
Volume change using elevation contours

Unlike today's DEMs, the standard elevation data 30 years ago and earlier were in the form of contour lines of the same elevation on maps (e.g. VAW/ETHZ 1967; Reinwarth 1973). Even today, contour lines from historic maps are often the only 
source of data available for information on glacier elevations further back in the past, which may, in Switzerland for example, be more than 140 years old (the Siegfried and Dufour maps; Oberli 1979).

\section{Geometrical-analytical contour approach}

One approach to measuring the volumetric changes in a glacier was used by Finsterwalder (1953, 1954). This elegant method involved superimposing contour lines from two different dates and measuring the area enclosed between each horizontally displaced contour line. To calculate the volume change of an elevation band $\left(d v_{u l}\right)$, the mean of the upper $\left(d F_{u}\right)$ and lower $\left(d F_{l}\right)$ difference area is multiplied by the contour interval $\left(\Delta h_{u l}\right)$ between both difference areas:

$$
d v_{u l}=\left(d F_{u}+d F_{l}\right) / 2 \times \Delta h_{u l}
$$

Eqn (1) therefore represents the volume of the enclosed 3-D prism (Finsterwalder 1953; Reinhardt and Rentsch 1986). Summing all volume changes per elevation band then leads to the overall volume change.

We used ArcGIS v.10.1 (ESRI, Inc.) to generate $25 \mathrm{~m}$ contour lines from both our ALS reference DEMs between 2525 and $3800 \mathrm{~m}$ a.s.l. Subsequently, the two sets of contour lines were intersected with the glacier outline of 2005 to avoid adding adjacent proglacial topographic changes, mostly from erosive processes, e.g. moraine instabilities (see Fig. 2b, northern moraine). The area differences at the 52 contour elevations (Fig. 2d) were then measured by summing all patches of each change in area, and the volume change was calculated according to Eqn (1).

To reveal the effects of scale when elevation contours were used, we used different sets of contour groups to calculate the overall volume change, i.e. we used all contour area differences ( $25 \mathrm{~m}$ elevation interval, one result), every second difference (50 $\mathrm{m}$ interval, two results as two alternating groups of $50 \mathrm{~m}$ contours exist from the $25 \mathrm{~m}$ dataset), every third difference ( $75 \mathrm{~m}$, three results), and so forth, up to $200 \mathrm{~m}$ contour intervals (eight sets).

The same area contour difference data were also used to test a slightly different algorithm proposed by Hofmann (1958). This is similar to Eqn (1), but it geometrically approximates the frustum of a cone instead of a prism:

$$
d V_{u l}=\left(d F_{u}+d F_{l}+\sqrt{d F_{u} \times d F_{l}}\right) / 3 \times \Delta h_{u l}
$$

\section{DEM generation from contour lines}

Another possibility is to use the contour lines of a survey year to directly interpolate a DEM using modern GIS techniques (e.g. Rivera and Casassa 1999; Vignon etal. 2003; Racoviteanu et al. 2007).We used the standard implementation and settings of the "topo-to-raster" method (earlier called TopoGrid) in ArcGIS v.10.1, based on the ANUDEM algorithm (Hutchinson 1989) to perform this task, and simulated the DEM generation from $25 \mathrm{~m}, 50 \mathrm{~m}$, and $100 \mathrm{~m}$ contour intervals for each year using a $25 \times 25 \mathrm{~m}$ target grid size. This method provided accurate interpolated DEM data, excelling other interpolation methods (Racoviteanu et al. 2007). These rasters were subsequently imported into MATLAB and bi-linearly interpolated using the built-in "interp2" function to generate a $1 \times 1 \mathrm{~m}$ grid. This step then allowed the rasters to be clipped with the high-resolution glacier outline of 2005 so that edge effects could be avoided. Finally, the DEMs were subtracted and volume changes calculated.

\section{Results}

\section{Volume change estimated with the ALS method}

Deriving the high point density geodetic change in volume of the Findelengletscher from ALS DEM differencing resulted in -48.1 million $\mathrm{m}^{3}$ volume change $(-3.66 \mathrm{~m}$ average elevation change) between 2005 and 2010 with the $1 \times 1 \mathrm{~m}$ raster resolution. All other results are presented here relative to this reference volume change, i.e. negative values indicate an overestimation of glacier thinning compared with the reference change.

Simulating DEMs with a coarser resolution up to $250 \mathrm{~m}$ raster cells led to results that randomly differed from the reference volume change, either underestimating or overestimating glacier mean elevation change (up to $\pm 7 \%$ ). Simulating stochastic uncertainties with the calculated values led to differences up to $\pm 8 \%$ in volume change for $250 \mathrm{~m}$ raster cells (2 standard deviations, Fig. 3), increasing in an exponential manner. Note that up to a raster cell size of $25 \mathrm{~m}$ almost no change took place in comparison to the highest resolution raster. With a running average of $25 \mathrm{~m}$ in the $\mathrm{x}$-axis direction (raster size) of the data, it seems the average differences never exceeded $\pm 1.5 \%$, although single values varied considerably.

The result with the low point density DEM showed a small bias of $+1.1 \%$ (which is the same as with $25 \mathrm{~m}$ raster cells) compared with the high 
point density DEM, i.e. a slight underestimation of glacier thinning. The accompanying stochastic uncertainties were very small as well (Tables 2 and $3)$. The elevation difference rasters showed no systematic, i.e. topography-dependent trend in the distribution of the elevation differences.

\section{Volume change estimated with the altimetry profile method}

The altimetry profile method resulted in an underestimation of the volume change of $18 \%$ (17\%) for a $1 \mathrm{~m}(25 \mathrm{~m})$ sampling distance compared with the reference DEM change. Developing the profile method fitted generally well with the reference DEM differencing method (Fig. 4), but multiple systematic effects were visible. These could, however, be attributed to physical causes. Thinning

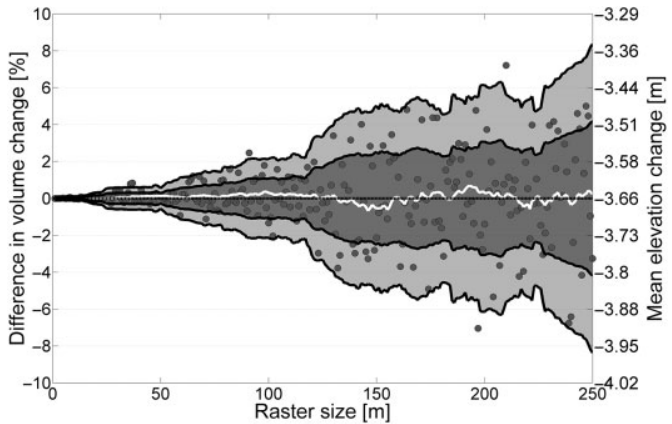

Fig. 3. Relative and absolute differences in the volume change from the ALS reference volume change due to the use of increasing raster cell sizes. Negative percentage values indicate the volume change was overestimated compared with the reference change. Each dot indicates a result that was actually calculated. The white line is the $25 \mathrm{~m}$ running average. The dark gray area shows a $25 \mathrm{~m}$ running standard deviation, and the light gray two standard deviations.

Table 2. Absolute values (val.) and variances (var.) of different thickness change methods and resolutions in the period 2005-2010.

\begin{tabular}{|c|c|c|c|c|c|c|c|c|c|c|}
\hline \multirow[t]{2}{*}{ Method } & \multicolumn{2}{|c|}{$1 \mathrm{~m}$} & \multicolumn{2}{|c|}{$25 \mathrm{~m}$} & \multicolumn{2}{|c|}{$50 \mathrm{~m}$} & \multicolumn{2}{|c|}{$100 \mathrm{~m}$} & \multicolumn{2}{|c|}{$200 \mathrm{~m}$} \\
\hline & Val. & Var. & Val. & Var. & Val. & Var. & Val. & Var. & Val. & Var. \\
\hline ALS_high & -3.7 & \pm 0.0 & -3.7 & \pm 0.0 & -3.7 & \pm 0.0 & -3.7 & \pm 0.0 & -3.7 & \pm 0.1 \\
\hline ALS_low & -3.6 & \pm 0.0 & -3.6 & \pm 0.0 & & & & & & \\
\hline ALS_profile & -3.0 & & -3.0 & & & & & & & \\
\hline CON_area & & & -3.8 & \pm 0.0 & -3.8 & \pm 0.1 & -3.7 & \pm 0.4 & -3.4 & \pm 0.5 \\
\hline CON_dem & & & -3.6 & & -3.7 & & -4.3 & & & \\
\hline
\end{tabular}

All numbers are in meters with the absolute values representing the average thickness change. The methods and the resolution and variance are explained in Table 4.

Table 3. Mean relative deviations (mean) and variances (var.) from the ALS reference thickness change (REF.) of different methods and resolutions in the period 2005-2010.

\begin{tabular}{|c|c|c|c|c|c|c|c|c|c|c|}
\hline \multirow[t]{2}{*}{ Method } & \multicolumn{2}{|c|}{$1 \mathrm{~m}$} & \multicolumn{2}{|c|}{$25 \mathrm{~m}$} & \multicolumn{2}{|c|}{$50 \mathrm{~m}$} & \multicolumn{2}{|c|}{$100 \mathrm{~m}$} & \multicolumn{2}{|c|}{$200 \mathrm{~m}$} \\
\hline & Mean & Var. & Mean & Var. & Mean & Var. & Mean & Var. & Mean & Var. \\
\hline ALS_high & REF. & \pm 0.1 & +0.1 & \pm 0.5 & +0.2 & \pm 0.6 & -1.3 & \pm 2.1 & -1.4 & \pm 6.1 \\
\hline ALS_low & +1.1 & \pm 0.1 & +1.1 & \pm 0.3 & & & & & & \\
\hline ALS_profile & +17.6 & & +16.7 & & & & & & & \\
\hline CON_area & & & -2.7 & & -2.7 & \pm 2.3 & -0.9 & \pm 11.5 & +8.2 & \pm 14. \\
\hline CON_dem & & & +0.8 & & -0.5 & & -18.3 & & & \\
\hline
\end{tabular}

All numbers are in percent. Negative mean values represent an overestimation of the thickness change compared with the reference change. The methods and the resolution and variance are explained in Table 4.

Table 4. Explanations for Tables 2 and 3. Note that 2 standard deviations enclose $95 \%$ of a normal distributed set of measurements.

\begin{tabular}{llll}
\hline Method & \multicolumn{1}{c}{ Description } & Meaning of resolution & Meaning of variance \\
\hline ALS_high & ALS high resolution flights & Side length of raster cell & 2 standard deviations \\
ALS_low & ALS low resolution flights & Side length of raster cell & 2 standard deviations \\
ALS_profile & ALS altimetry profile & Sampling distance & Max. deviation from mean \\
CON_area & Contour area approach & Contour interval used & \\
CON_dem & Contours to DEM approach & Contour interval used & \\
\hline
\end{tabular}


was underestimated in the upper section of the Findelengletscher, which has the largest glacier area per $10 \mathrm{~m}$ elevation band. There the accumulation regime is locally dependent on wind erosion and deposition, as well as on the highly inhomogeneous accumulation pattern. In contrast, the altimetry profile method overestimated the volume change at the tongue.

\section{Volume change estimated with the contour line methods}

Summing the volume changes using all contours (25 $\mathrm{m}$ interval) led to a difference in volume

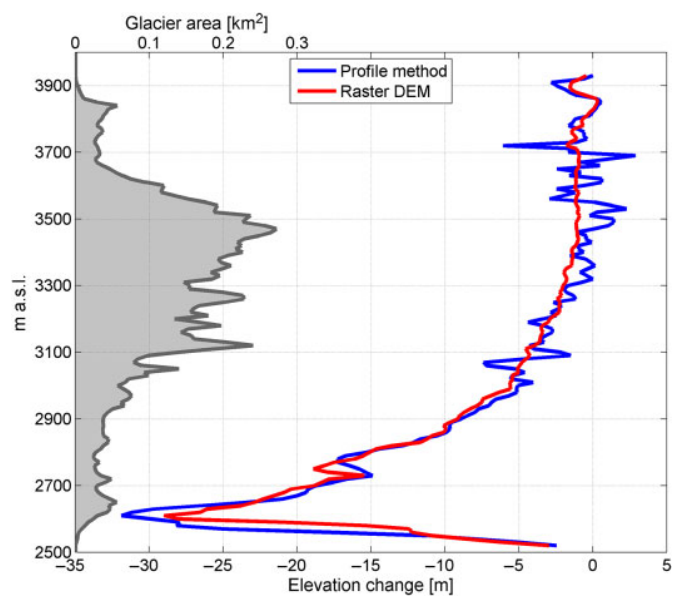

Fig. 4. Local elevation changes from the profile method and from all DEM raster cells for $10 \mathrm{~m}$ elevation bands. The gray area to the left is the hypsometry of the Findelengletscher, also shown in $10 \mathrm{~m}$ bands. change of $-2.7 \%$ for the Findelengletscher compared with the reference change (Tables 2 and 3). Note that both contour area change methods produced very similar results, which is why only the result with the Finsterwalder method $(1953,1954)$ is shown. Both methods overestimated thinning in the five-year period covered, with a decreasing thinning trend for increasing contour intervals (Fig. 5). Intervals smaller than $125 \mathrm{~m}$ showed an overestimation of glacier thinning for average values. Using $125 \mathrm{~m}$ and larger intervals, the deviation of the average changed its sign to underestimate thinning by up to $8.2 \%$. The results with the $200 \mathrm{~m}$ interval varied greatly, with random deviations ranging between $-3 \%$ and $23 \%$.

Instead of using the area changes between multitemporal contour lines at the same elevation, we used the contours in addition to generate DEMs and subsequently subtracted these surfaces similarly to the ALS DEMs. Using $25 \mathrm{~m}(50 \mathrm{~m}, 100 \mathrm{~m})$ contour intervals resulted in a relative volume change difference of $0.8 \%(-0.5 \%,-18.3 \%)$ compared with the reference change (Tables 2 and 3 ).

\section{Discussion}

Scaling effects in the ALS volume change

The ALS point measurements were not distributed evenly throughout the study area and hence neither in a single raster cell. Consequently, the mean elevation of a raster cell will be influenced by the irregular distribution of the enclosed points. As the influence of this effect increases with increasing raster cell sizes, we used the $1 \times 1 \mathrm{~m}$ raster elevations as the reference for all subsequent

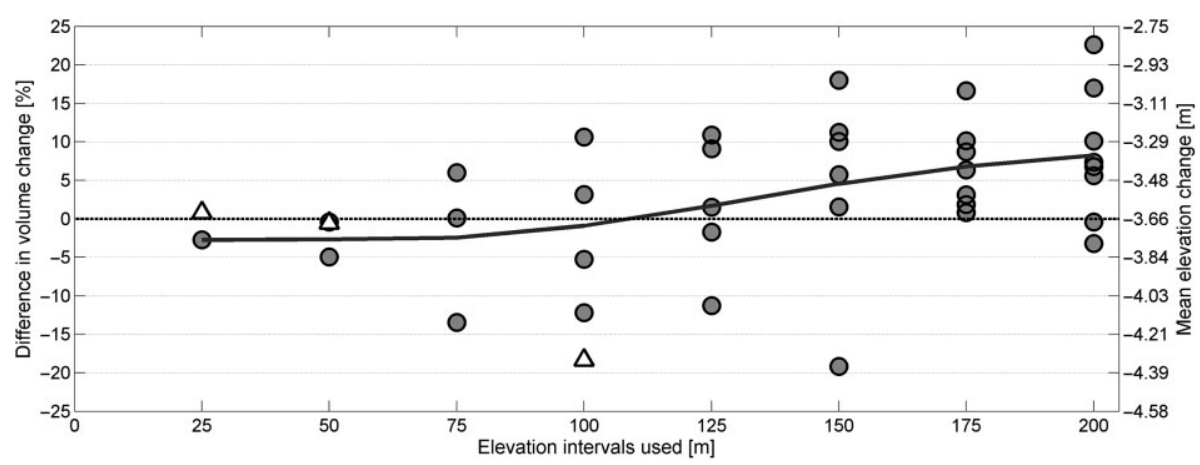

Fig. 5. Relative and absolute differences in the volume change from the ALS reference change due to the use of different contour intervals. Negative percentage values indicate the volume change was overestimated compared with the reference change. Each dot represents a result using the Finsterwalder (1954) approach; the black line is the average of all results per elevation interval. The triangles represent the differences in volume from the reference change of DEMs calculated from the contours. 
calculations instead of the ALS point measurements. To fill the resampled (larger) raster cells, linear interpolations were made from the closest raster elevations in the reference raster. This approach therefore simulated high-precision data acquisition at a small location, and provided the elevation values for larger raster cells. Taking the average of all raster cell elevation values within a larger cell would better represent medium resolution DEMs from satellite sensors (i.e. ASTER, SRTM). However, it is presumed that our approach (Fig. 3) leads to larger variation, and thus should still be valid for these situations.

A raster cell size of up to of $25 \mathrm{~m}$ was found to be a stable size for measuring volume change in the Findelengletscher. Our results suggest that higher-resolution DEMs would not result in very much improved volume differences. Lowering the resolution to $30 \mathrm{~m}$ (Fig. 2e; similar to the ASTER GDEM product; Tachikawa et al. 2011) introduced an uncertainty of $\pm 0.5 \%$, while lowering it to $90 \mathrm{~m}$ (Fig. 2f; similar to the global SRTM product; Farr et al. 2007) produced an uncertainty of $\pm 2 \%$. These results mainly reflect the smaller sampling population as raster pixel size increases since the precision of the estimates remains the same from our resampling strategy in this experiment. Although the exponentially increasing absolute deviations are expected to be valid for different glaciers, the result depends on the geometric shape of the glacier, i.e. the size and hypsometry of the glacier, the surface roughness, the mass balance pattern, and the time interval between two geodetic campaigns. In a test comparing an additional ALS DEM from 2009 (Joerg et al. 2012) with the DEM from 2010, the absolute variation remained similar to the five-year study period, whereas the relative variations tripled. With little mass change, be it due to a short acquisition interval or a low annual turnover, the relative uncertainties could thus be large. The geometric shape of a glacier is another major source of uncertainty. The Findelengletscher has an average glacier tongue width of approximately $500 \mathrm{~m}$, which is where the most marked elevation change took place. Here, the relative raster resolution is more important for obtaining an accurate result as edge effects show up more with larger raster sizes. In contrast, in the large accumulation area, a lower raster resolution is unlikely to impair the result much.

The standard deviation increases with raster size, depending on the location of the grid. If the centre of a raster cell is on the edge of the glacier, the elevation change for the entire raster area is represented by the centre value, even though there would be no elevation change in a large part of the cell. Depending on the number and the location of such occurrences, the calculated elevation change varies, sometimes strongly, with raster resolution. As we were using a raster increment of just $1 \mathrm{~m}$ per calculation step, a deviation resulting from a running average/standard deviation serves as an indicator of variability (Fig. 3); two standard deviations are regarded as a reliable boundary for more extreme values. With increasing raster sizes, a single measurement could therefore be an extreme deviation from the actual value only because of the location of the raster grid.

The underestimation of glacier thinning with systematically higher raster elevations of the lower point density data (cf. Tables 2 and 3 ) could be an effect of scale due to the interpolation of data voids into a $1 \times 1 \mathrm{~m}$ grid, and the resulting smoothing of the glacier's surface. Another explanation could be that the extrapolation of the volume change into the unmeasured area introduced a bias. No clear spatially systematic vertical shift was detected qualitatively between the high and low point density DEMs from 2010. In addition, a systematic horizontal DEM shift would lead to a hill-shading effect, showing the topography in the DEM difference plot (Nuth and Kääb 2011), but no such effect was found either.

\section{Assessment of the profile method}

The altimetry profile method considerably underestimated glacier thinning. It can, however, map surface changes in a large number of glaciers more cheaply than the airborne laser scanning method, but the resulting extrapolated volume change differs considerably from that for the entire raster DEM. Unexpectedly, the largest part of the error does not appear to originate from the overestimation of the elevation change at the tongue (cf. Arendt et al. 2002; Berthier et al. 2010), but rather from the underestimation of the elevation change in the large accumulation area. This underestimation is probably connected with the complex accumulation patterns in the area caused by local wind erosion and deposition, as well as the movement of crevasses, which lead to variation in the local elevation changes. Overall, the reproduction of the glacier-wide change trend is quite accurate, possibly because the melt pattern of the 
Findelengletscher is relatively simple. The almost debris-free westerly exposed glacier tongue has an exposition-dependent melt pattern, with stronger melting in the more southerly exposed ice and less melting to the north. The centreline therefore roughly represents the average melt on the tongue, although the influence of the restricted possible melt on the edge of the tongue is less prominent at the centreline and is expected to be relatively smaller in the five-year study period than it would be over a longer time span.

\section{Scaling effects with the contour method}

The geometrical-analytical contour approach resulted in values $2.7 \%$ more negative compared with those in the reference change when all $25 \mathrm{~m}$ contours were used. This is a very accurate result in comparison with that obtained with the high point density multi-temporal raster DEMs. Using contour intervals larger than $75 \mathrm{~m}$ resulted in our case in deviations of mean elevation change by up to $\pm 10 \%$ compared with the reference change. The average of all groups of contours available shows a systematic decrease in glacier thinning with increasing contour intervals. This is due to the fact that the glacier's tongue is increasingly undersampled compared with the number of contours in the large accumulation area, which is changing less rapidly. The most melt took place in the lowest part of the glacier tongue. However, in our simulation and dependent on the slope of the glacier, the first $200 \mathrm{~m}$ contour set does not start until $200 \mathrm{~m}$ above the glacier's terminus, thus missing the areas where the most melt occurs and consequently underestimating the overall melt.

In historical maps, the positions of the map's contours on glacier and snow surfaces and in high mountain topography may contain large errors because of the difficulty of mapping such areas. The accumulation areas were sometimes inaccessible for surveyors on the ground, making it impossible for them to conduct high-accuracy campaigns on glacier surfaces. As a result, older volume change measurements may be very inaccurate. Later aerial images became available and were used to calculate elevations photogrammetrically. However, snow in the accumulation area often resulted in little image texture, and shadowing effects also made it difficult to position the contour lines accurately in the derived maps. Our simulation showed that the method to derive the volume change seemed in itself to be accurate nevertheless for contour lines with small elevation intervals independent of the quality of the contour line positions. With larger contour intervals, however, systematic errors could be larger.

The second approach for generating DEMs from contours resulted in volume changes similar to the ALS DEMs when using $25 \mathrm{~m}$ and $50 \mathrm{~m}$ contour intervals. The DEMs generated from two $100 \mathrm{~m}$ contour datasets were not able to reproduce the volume change in the Findelengletscher sufficiently well, and overestimated glacier thinning by $18 \%$. In this case, the horizontal distance between two contour lines is too large to reproduce the smaller scale glacier changes. However, with the two shorter contour intervals, the DEM differencing method outperformed the geometricalanalytical methods not only in terms of accuracy, but also in the time needed to calculate the results. DEM differencing is therefore the method of choice.

\section{Conclusions}

We used multi-temporal high-resolution ALS data from 2005 and 2010 to evaluate standard methods for measuring volumetric change in a glacier, using the Findelengletscher as an example as it is a typical valley glacier in the Swiss Alps. Two highresolution DEMs from ALS with an average point density of up to 14 laser returns per square meter served as the reference dataset. We compared the estimates of glacier volume change obtained with these datasets with the results from an economically optimized high-altitude ALS over-flight with reduced point density, and various datasets analyzed with different volumetric change assessment methods and on different spatial scales.

Using less expensive settings, i.e. high-altitude, large scan angles, and low pulse repetition frequency, introduced a small bias $(1.1 \%)$, which can be corrected by co-registration of nonglacierized terrain. Nonetheless, it was still possible to maintain both the horizontal accuracy and the very small volume change uncertainty $(<1 \%)$. The optimized ALS setup reduced the survey effort by $90 \%$, but still provides a point density of 0.4 laser returns per square meter, which is sufficient for accurately assessing glacier volume changes.

Most current glacier volume change studies are based on DEM differencing at various spatial resolutions. Simulating the scaling effect of different raster resolutions from $1 \times 1 \mathrm{~m}$ (reference ALS) to 
$250 \times 250 \mathrm{~m}$ did not result in any volume change bias, but in an exponential increase in the random error. The corresponding uncertainty was well below $1 \%$ for a resolution of $25 \times 25 \mathrm{~m}$, but increased to $2 \%(6 \%)$ for a pixel size of $100 \mathrm{~m}$ (200 m).

If photogrammetric plotters or topographic maps are used, elevation contour lines have to be relied on in assessing glacier volume changes. Older analytical methods using geometric approaches can be very laborious, but results for contour line intervals up to $50 \mathrm{~m}$ are reasonable, with a small negative bias of $3 \%$. However, for contour line intervals larger than $100 \mathrm{~m}$, we found a positive trend in the bias (up to $+8 \%$ for $200 \mathrm{~m}$ intervals) as it does not cover the very variable glacier tongue, and a random error of $\pm 14 \%$. GIS-based interpolation (based on the ANUDEM algorithm) produced similar results, with even stronger biases for contour line intervals $>50 \mathrm{~m}$, but it is much more efficient.

Studies based on laser altimetry typically assess the glacier elevation changes along central profile lines. We found strong local biases with opposite signs: negative on the glacier tongue, probably due to its limited lateral ice thickness, and both positive and negative in the accumulation area, probably according to whether the profile line covered deposition (positive) or erosion (negative). The overall bias was quite large (18\%), and its (positive) sign depended both on the location of the profile and on the glacier hypsometry.

Overall, we can confirm that ALS DEM differencing is currently the fastest and most accurate method to derive glacier volume changes and scaling issues have a limited impact up to a spatial resolution of $50 \mathrm{~m}$. Other methods, e.g. contour method with intervals larger than $50 \mathrm{~m}$ and profile method, can introduce systematic and random errors.

\section{Acknowledgements}

We are grateful to Wilfried Haeberli and Michael Schaepman for their valuable support with this project. Many thanks to Christopher Nuth and an anonymous reviewer for their constructive comments which helped to improve the manuscript considerably, and to Silvia Dingwall for polishing the English. We thank BSF Swissphoto for the acquisition of the ALS data and their continuous support. This project was supported by the Swiss energy utility Axpo.
Philip Claudio Joerg and Michael Zemp, Department of Geography, University of Zurich, Winterthurerstrasse 190, CH-8057 Zurich, Switzerland

E-mail: philip.joerg@geo.uzh.ch; michael.zemp@geo.uzh.ch

\section{References}

Arendt, A.A., Echelmeyer, K.A., Harrison, W.D., Lingle, C.S. and Valentine, V.B., 2002. Rapid wastage of Alaska glaciers and their contribution to rising sea level. Science, 297, 382-386. doi: 10.1126/science. 1072497

Berthier, E., Schiefer, E., Clarke, G.K.C., Menounos, B. and Rémy, F., 2010. Contribution of Alaskan glaciers to sealevel rise derived from satellite imagery. Nature Geoscience, 3, 92-95. doi: 10.1038/ngeo 737

Cogley, J.G., 2009. Geodetic and direct mass-balance measurements: Comparison and joint analysis. Annals of Glaciology, 50, 96-100. doi: 10.3189/172756409787769744

Farr, T.G., Rosen, P.A., Caro, E., Crippen, R., Duren, R., Hensley, S., Kobrick, M., Paller, M., Rodriguez, E., Roth, L., Seal, D., Shaffer, S., Shimada, J., Umland, J., Werner, M., Oskin, M., Burbank, D. and Alsdorf, D.E., 2007. The shuttle radar topography mission. Reviews of Geophysics, 45. doi: 10.1029/2005RG000183

Finsterwalder, R., 1953. Die zahlenmässige Erfassung des Gletscherrückgangs an Ostalpengletschern. Zeitschrift für Gletscherkunde und Glazialgeologie, 2, 189-239.

Finsterwalder, R., 1954. Photogrammetry and glacier research with special reference to glacier retreat in the Eastern Alps. Journal of Glaciology, 2, 306-315.

Finsterwalder, S., 1897. Der Vernagtferner. Wissenschaftliche Ergänzungshefte zur Zeitschrift des Deutschen und Österreichischen Alpenvereins, 1, 1-96.

Hofmann, W., 1958. Der Vorstoss des Nisqually-Gletschers am Mt. Rainier, U.S.A., von 1952 bis 1956. Zeitschrift für Gletscherkunde und Glazialgeologie, 4, 47-60.

Hutchinson, M.F., 1989. A new procedure for gridding elevation and stream line data with automatic removal of spurious pits. Journal of Hydrology, 106, 211-232.

Joerg, P.C., Morsdorf, F. and Zemp, M., 2012. Uncertainty assessment of multi-temporal airborne laser scanning data: A case study on an Alpine glacier. Remote Sensing of Environment, 127, 118-129. doi: 10.1016/j.rse .2012 .08 .012

Mercanton, P.L., 1916. Vermessungen am Rhonegletscher/ Mensuration au glacier du Rhone: 1874-1915. Neue Denkschrift der Schweizerischen Naturforschenden Gesellschaft, 52, 189.

Nuth, C. and Kääb, A., 2011. Co-registration and bias corrections of satellite elevation data sets for quantifying glacier thickness change. The Cryosphere, 5, 271-290. doi: 10.5194/tc-5-271-2011

Oberli, A., 1979. Dufour-Karte und Siegfried-Atlas. In: Unsere Landeskarten. Schweizerischer Alpen-Club in cooperation with the Federal Office of Topography, Berne. 72 p.

PSFG, 1967. Fluctuations of Glaciers 1959-65. Permanent Service on Fluctuations of Glaciers, Zurich, Switzerland.

Racoviteanu, A.E., Manley, W.F., Arnaud, Y. and Williams, M.W., 2007. Evaluating digital elevation models for glaciologic applications: an example from Nevado Coro- 
puna, Peruvian Andes. Global and Planetary Change, 59, 110-125. doi: 10.1016/j.gloplacha.2006.11.036

Reinhardt, W. and Rentsch, H., 1986. Determination of changes in volume and elevation of glaciers using digital elevation models for the Vernagtferner, Ötztal Alps, Austria. Annals of Glaciology, 8, 151-155.

Reinwarth, O., 1973. Maps of Vernagtferner 1889-1969 (3 sheets). Permanent Service on Fluctuations of Glaciers, Zurich, Switzerland.

Rivera, A. and Casassa, G., 1999. Volume changes on Pio XI glacier, Patagonia: 1975-1995. Global and Planetary Change, 22, 233-244. doi: 10.1016/S09218181(99)00040-5

Sold, L., Huss, M., Hoelzle, M., Andereggen, H., Joerg, P.C. and Zemp, M., 2013. Methodological approaches to infer end-of-winter snow distribution on alpine glaciers. Journal of Glaciology, 59, 1047-1059. doi: 10.3189/ 2013JoG13J015

Tachikawa, T., Hato, M., Kaku, M. and Iwasaki, A., 2011. Characteristics of ASTER GDEM version 2. Vancouver, BC. 3657-3660 .

VAW/ETHZ, 1967. Map of Aletsch Glacier (Aletschgletscher). Permanent Service on Fluctuations of Glaciers, Zurich, Switzerland.

Vignon, F., Arnaud, Y. and Kaser, G., 2003. Quantification of glacier volume change using topographic and ASTER
DEMs: a case study in the Cordillera Blanca. 2003 IGARSS: Learning From Earth's Shapes and Colours, Toulouse, France. 2605-2607.

WGMS, 2008. Global Glacier Changes: Facts and Figures. UNEP, World Glacier Monitoring Service, Zurich, Switzerland.

WGMS, 2012. Fluctuations of Glaciers 2005-2010. ICSU(WDS)/IUGG(IACS)/UNEP/UNESCO/WMO,

World Glacier Monitoring Service, Zurich, Switzerland. Publication based on database version: doi: 10.5904/ wgms-fog-2012-11

Zemp, M., Hoelzle, M. and Haeberli, W., 2009. Six decades of glacier mass-balance observations: A review of the worldwide monitoring network. Annals of Glaciology, 50, 101-111. doi: 10.3189/172756409787769591

Zemp, M., Thibert, E., Huss, M., Stumm, D., Rolstad Denby, C., Nuth, C., Nussbaumer, S.U., Moholdt, G., Mercer, A., Mayer, C., Joerg, P.C., Jansson, P., Hynek, B., Fischer, A., Escher-Vetter, H., Elvehøy, H. and Andreassen, L.M., 2013. Reanalysing glacier mass balance measurement series. The Cryosphere, 7, 1227-1245. doi: 10.5194/tc-7$1227-2013$

Manuscript received 5 Jul., 2013; revised and accepted 5 Dec., 2013 